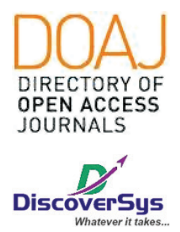

Published by DiscoverSys

\title{
Perbedaan stress kerja pada perawat di ruang unit gawat darurat dengan perawat di ruang rawat inap Rumah Sakit "S" di Kota Denpasar tahun 2017
}

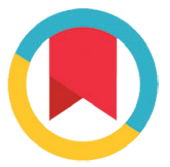

CrossMark

\author{
Putu Dharma Putri Mahastuti, ${ }^{1 *}$ I Made Muliarta, ${ }^{2}$ Luh Made Indah Sri Handari Adiputra ${ }^{2}$
}

\section{ABSTRACT}

Introduction: Job stress can be interpreted as a demand or stressor that can cause a complaint or stress caused by work. This study was conducted to know the difference of job stress that happened at Emergency Room and inpatient ward at Sanglah Hospital Denpasar. Method: This study used cross sectional analytic design and the data was analyze from the job stress questionnaire that was validated. Questionnaires were given to nurses that working in the emergency room and inpatient ward at Sanglah Hospital Denpasar. The samples size is 116 subjects.

Result: The result is 7 nurses at the emergency room (12.1\%) and 29 inpatients (50\%) had mild stress, 33 ER nurses (56.9\%) and
25 inpatients (43.1\%) experienced moderate stress meanwhile, at 18 ER nurses (31\%) and 4 inpatients (6.9\%) had severe stress. Based on statistical test to find out the difference of work stress using Mann-Whitney test, the result of Mann-Whitney $U$ value is 841.0 and $p$ value is 0.000 . So it can be concluded that $p$ value $<0.05$.

Conclusion: Thus, there is a significant difference in the level of work stress between nurses who served in the emergency room with inpatient care.
1Program Studi Pendidikan Dokter, Fakultas kedokteran, Universitas Udayana

${ }^{2}$ Bagian IImu Faal, Fakultas Kedokteran, Universitas Udayana

${ }^{*}$ Correspondence to:

Putu Dharma Putri Mahastuti, Program Studi Pendidikan Dokter, Fakultas kedokteran, Universitas Udayana

dharmaputrimahastuti@yahoo.com

Diterima: 06-04-2018

Disetujui: 07-05-2018

Diterbitkan: 01-08-2019

Keywords: Job Stress, Emergency Room, Inpatient Ward, Nurse.

Cite This Article: Mahastuti, P.D.P., Muliarta, I.M., Adiputra, L.M.I.S.H. 2019. Perbedaan stress kerja pada perawat di ruang unit gawat darurat dengan perawat di ruang rawat inap Rumah Sakit "S" di Kota Denpasar tahun 2017. Intisari Sains Medis 10(2): 284-289. D0I: 10.15562/ism. v10i2.212

\section{ABSTRAK}

Latar Belakang: Stres kerja memiliki arti sebagai tuntutan atau stressor yang dapat menimbulkan suatu keluhan atau stres yang diakibatkan oleh pekerjaan. Penelitian yang dilakukan ini untuk mengetahui adanya perbedaan stres kerja yang terjadi di ruang Unit Gawat Darurat dengan ruang Rawat Inap di Rumah Sakit Sanglah Denpasar.

Metode: Penelitian ini menggunakan rancangan analitik potong lintang. Data dikumpulkan dengan kuesioner yang dibagikan kepada perawat. Kuesioner stres kerja yang digunakan telah diuji validasi. Kuesioner dibagikan kepada perawat yang bertugas di ruang unit gawat darurat serta ruang rawat inap RSUP Sanglah Denpasar. Pengambilan sampel dengan teknik purposive sampling. Jumlah total seluruh sampel yang didapatkan adalah 116 subyek terdiri atas
58 perawat UGD dan 58 perawat di ruang rawat inap. Data dianalisis menggunakan program SPSS versi 24.

Hasil: Dari 116 subyek didapatkan, 7 perawat UGD $(12,1 \%)$ dan 29 perawat rawat inap (50\%) mengalami stres ringan, 33 perawat UGD $(56,9 \%)$ dan 25 perawat rawat inap $(43,1 \%)$ mengalami stres sedang, dan 18 perawat UGD (31\%) dan 4 perawat rawat inap (6,9\%) mengalami stres berat. Berdasarkan uji statistik untuk mengetahui adanya perbedaan stres kerja menggunakan uji Mann-Whitney diperoleh hasil nilai Mann-Whitney $U$ sebesar 841,0 dan nilai p value yang didapatkan sebesar 0,000 .

Simpulan: terdapat perbedaan secara bermakna terhadap tingkatan stres kerja antar perawat yang bertugas di ruang Unit Gawat Darurat dengan Rawat Inap.

Kata Kunci : Stres Kerja, Unit Gawat Darurat, Rawat Inap, Perawat

Cite Pasal Ini: Mahastuti, P.D.P., Muliarta, I.M., Adiputra, L.M.I.S.H. 2019. Perbedaan stress kerja pada perawat di ruang unit gawat darurat dengan perawat di ruang rawat inap Rumah Sakit "S" di Kota Denpasar tahun 2017. Intisari Sains Medis 10(2): 284-289. D0I: 10.15562/ism.v10i2.212

\section{PENDAHULUAN}

Perawat merupakan salah satu tenaga professional yang bekerja di rumah sakit dan memiliki peran penting dalam pelayanan kesehatan. Tugas yang dilakukan perawat mengharuskan mereka kontak dan berinteraksi dengan pasien serta keluarga pasien terutama pasien yang rumit dan kritis sehingga dapat menjadi pemicu timbulnya stres kerja. $^{1,2}$ 
Stres diartikan sebagai ketidakmampuan individu untuk mengatasi ancaman dari sesuatu sehingga dapat mempengaruhi kesehatan fisik individu tersebut. ${ }^{1}$ Stres kerja dapat diartikan sebagai emosi negatif serta respon fisik yang dapat dialami apabila tuntutan kerja yang didapat tidak sesuai dengan kemampuan karyawan.,

World Health Organization (WHO) melaporkan lebih dari setengah karyawan pada negara industri mengalami stres kerja. ${ }^{4}$ Hampir 11 juta orang mengalami stres kerja di Amerika Serikat dan dikatakan bahwa stres kerja merupakan masalah terbesar dan terpenting dalam kehidupan. ${ }^{4}$ Stres kerja dapat dihubungkan dengan masalah psikologi dan fisik. ${ }^{5}$ Beberapa hal yang dapat menjadi pencetus kondisi stres pada perawat, yaitu tingginya beban kerja, risiko terinfeksi penyakit, permasalahan dalam keluarga, jauhnya tempat tinggal dari tempat kerja, kemacetan lalu lintas, serta fasilitas yang kurang di tempat kerja. ${ }^{2}$ Berdasarkan studi yang dilakukan PPNI tahun 2006, 50,9\% tenaga kerja perawat di Indonesia dari empat provinsi menderita stres kerja dikarenakan tuntutan kerja yang tinggi dan menghabiskan banyak waktu, serta rendahnya pendapatan dan insentif yang diberikan. ${ }^{1}$ Stres yang tidak ditangani dengan tepat dapat menyebabkan keluhan jasmani, psikologis maupun mempengaruhi pelayanan perawat kepada pasien. ${ }^{2}$

Penulis menyadari tingginya peranan perawat di dunia kesehatan sehingga penting untuk dilakukannya penelitian mengenai perawat yang menderita stres kerja di Rumah Sakit Denpasar, Sehingga peneliti melakukan studi mengenai perbedaan stres kerja pada perawat di UGD dan rawat inap di Rumah Sakit Sanglah Kota Denpasar, Bali.

\section{METODE}

Penelitian ini merupakan penelitian analitik dengan rancangan potong lintang. Penelitian menggunakan sampel seluruh perawat yang bekerja di ruang UGD dan perawat di ruang rawat inap RS Sanglah di Denpasar pada tahun 2017. Besar sampel dihitung menggunakan formula dua kelompok independen. Sampel penelitian dipilih secara purposive dari populasi target sampai besar sampel terpenuhi. Besar sampel ditentukan 60 subyek untuk tiap kelompok berdasarkan hasil perhitungsn sampel dan antisipasi drop out sebesar $25 \%$. Kriteria inklusi penelitian ini yaitu, masa kerja minimal satu tahun, bersedia berpartisipasi sebagai subjek dalam penelitian serta menandatangani lembar persetujuan subjek penelitian. Data penelitian ini merupakan data primer, dimana semua data diperoleh dari hasil penyebaran kuesioner. Alat pengumpulan data yang digunakan yaitu kuesioner stres kerja dari penelitian Juniar tahun 2005 yang telah dimodifikasi oleh Jusnimar tahun 2012. ${ }^{6}$ Penilainan pengukuran tingkat stres terdiri dari 16 pertanyaan dengan parameter: konflik yang dialami dengan dokter, teman sejawat, kepala ruangan, keluarga pasien, beban kerja, keterbatasan fasilitas, kematian dan kesakitan pasien. Pengukuran ini menggunakan skala likert, dengan mengisi tanda checklist $(\sqrt{ })$. Interpretasi tingkat stress dikelompokkan menjadi sebagai berikut, apabila nilai skor total 16-32; stres ringan, 32-48; stress sedang, dan 48-64; stres berat. ${ }^{6}$

Uji validitas dan reliabilitas kuesioner ini telah dilakukan oleh Jusnimar pada tahun 2012..$^{6}$ Nilai uji validitas yang didapatkan antara 0,539-0,810 dan dinyatakan valid. Uji reliabilitas mendapatkan hasil alpha cronbach 0,904 dan kuesioner tersebut dikatakan reliable (IK 95\%). ${ }^{6}$

Penelitian ini telah mendapatkan persetujuan dari komisi etik Fakultas Kedokteran Universitas Udayana dan ijin penelitian dari RSUP Sanglah. Penelitian telah dilakukan dari bulan Mei sampai September 2017.

\section{HASIL}

Telah dilakukan penelitian terhadap 116 subyek yang memenuhi kriteria inklusi dan eksklusi, dimana pada masing-masing kelompok yaitu pada ruang UGD 58 subyek dan ruang rawat inap 58 subyek.

Dapat dilihat pada Tabel 1, dari 116 subyek dalam penelitian ini terdapat 46 perawat UGD $(79,3 \%)$ dan 48 perawat rawat inap $(82,7 \%)$ yang memiliki usia antara 20 sampai 40 tahun. Terdapat 12 perawat UGD $(20,7 \%)$ dan 10 perawat rawat inap $(17,3 \%)$ yang memiliki usia antara 41 sampai dengan 65 tahun. Rerata usia perawat yang paling banyak pada ruang UGD dan rawat inap adalah usia 20-40 tahun.

Berdasarkan jenis kelamin pada Tabel 1. terdapat 13 perawat UGD $(22,4 \%)$ dan 2 perawat rawat inap $(3,4 \%)$ yang berjenis kelamin laki-laki. Sedangkan terdapat 45 perawat UGD (77,6\%) dan 56 perawat rawat inap $(96,6 \%)$ yang berjenis kelamin perempuan. Rerata jenis kelamin perawat yang paling tinggi di ruang UGD dan rawat inap adalah Perempuan.

Berdasarkan tingkat pendidikan pada Tabel 1. terdapat 43 perawat UGD $(74,1 \%)$ dan 50 perawat rawat inap $(86,2 \%)$ dengan tingkat pendidikan D3 atau D4 keperawatan, 15 perawat UGD $(25,9 \%)$ dan 8 perawat rawat inap $(13,8 \%)$ dengan tingkat pendidikan S1 keperawatan. Rerata tingkat pendidikan tertinggi pada perawat ruang UGD dan rawat inap adalah D3/D4 Keperawatan. 
Berdasarkan status perkawinan terdapat 42 perawat UGD $(72,4 \%)$ dan 51 perawat rawat inap $(88 \%)$ telah menikah. Sedangkan 16 perawat UGD $(27,6 \%)$ dan 7 perawat rawat inap (12\%) belum menikah. Rerata status perkawinan perawat pada ruang UGD dan rawat inap yang paling banyak yaitu menikah.

Berdasarkan masa kerja terdapat 21 perawat UGD (36,2\%) dan 18 perawat rawat inap (31\%) dengan lama kerja 1 sampai dengan 5 tahun, 17 perawat UGD (29,3\%) dan 24 perawat rawat inap $(41,4 \%)$ dengan lama kerja 6 tahun sampai dengan 10 tahun, 20 perawat UGD $(34,5 \%)$ dan 16 perawat rawat inap $(27,6 \%)$ dengan lama kerja lebih dari 10 tahun. Rerata masa kerja tertinggi yaitu 6-10 tahun.

Berdasarkan tingkat stres kerja terdapat 1 perawat UGD $(1,7 \%)$ dan 25 perawat rawat inap $(43,1 \%)$ mengalami stres ringan, 39 perawat UGD $(67,2 \%)$ dan 29 perawat rawat inap (50\%) mengalami stres sedang, pada 18 perawat UGD (31\%) dan 4 perawat rawat inap $(6,9 \%)$ mengalami stres berat. Tingkat stress tertinggi pada kedua ruangan adalah stress sedang

\section{Analisis Bivariat}

Uji Chi-Square digunakan pada penelitian ini untuk mengetahui apakah terdapat hubungan diantara variabel bebas (usia, jenis kelamin, tingkat pendidikan, status perkawinan, masa kerja, dan tempat kerja) dengan variabel tergantung (tingkat stres).
Dari hasil uji statistik hubungan antara stres kerja dengan usia menggunakan uji korelasi pearson chi-Square dapat dilihat pada Tabel 2. diketahui nilai p sebesar 0,571. Berdasarkan kriteria yang ada, hubungan antara dua variabel $p>0,05$ atau Ho diterima. Dengan demikian, dapat disimpulkan bahwa Usia tidak berhubungan dengan tingkat stress.

Hubungan antara stres kerja dengan jenis kelamin pada Tabel 2 didapatkan nilai $\mathrm{p}$ sebesar $0,142$. Nilai $p$ value 0,142 ( $p>0,05)$, sehingga, dapat disimpulkan bahwa tidak ada hubungan antara jenis klamin dengan tingkat stres kerja.

Hubungan antara stres kerja dengan status perkawinan pada Tabel 2 didapatkan nilai p sebesar 0,462 . Sehingga dapat ditentukan bahwa $p$ value $0,462(\mathrm{p}>0,05)$ atau Ho diterima. Dengan demikian, dapat disimpulkan bahwa Status Perkawinan tidak berhubungan dengan tingkat stress.

Hasil hubungan antara stres kerja dengan tempat kerja pada Tabel 2 didapatkan nilai p sebesar 0,000 $(\mathrm{p}<0,05)$, dengan demikian, didapatkan tempat kerja berhubungan dengan tingkat stress.

Tingkat stres sedang berat paling tinggi didapatkan di ruang UGD sebanyak 51 orang $(87,9 \%)$ sedangkan pada ruang rawat inap didapatkan stres sedang berat sebnayak 22 orang $(37,9 \%)$.

Hasil hubungan antara stres kerja dengan tingkat pendidikan pada Tabel 2 nilai p sebesar 0,233. Sehingga dapat. ditentukan bahwa $\mathrm{p}$ value 0,233 ( $p>0,05)$, dengan demikian, dapat disimpulkan bahwa Tingkat pendidikan tidak berhubungan dengan stres kerja.

Tabel 1 Karakteristik dasar subyek

\begin{tabular}{|c|c|c|c|c|c|}
\hline \multirow{2}{*}{ Karakteristik } & & \multicolumn{2}{|c|}{ UGD } & \multicolumn{2}{|c|}{ Rawat Inap } \\
\hline & & Jumlah (n) & Persentase (\%) & Jumlah (n) & Persentase (\%) \\
\hline \multirow[t]{2}{*}{ Usia } & 20-40 tahun & 46 & 79,3 & 48 & 82,7 \\
\hline & 41-65 tahun & 12 & 20,7 & 10 & 17,3 \\
\hline \multirow[t]{2}{*}{ Jenis Kelamin } & Laki-laki & 13 & 22,4 & 2 & 3,4 \\
\hline & Perempuan & 45 & 77,6 & 56 & 96,6 \\
\hline \multirow{2}{*}{$\begin{array}{l}\text { Tingkat } \\
\text { Pendidikan }\end{array}$} & D3/D4 Keperawatan & 43 & 74,1 & 50 & 86,2 \\
\hline & S1 Keperawatan & 15 & 25,9 & 8 & 13,8 \\
\hline \multirow[t]{2}{*}{ Status Perkawinan } & Menikah & 42 & 72,4 & 51 & 88 \\
\hline & Belum Menikah & 16 & 27,6 & 7 & 12 \\
\hline \multirow[t]{3}{*}{ Masa Kerja } & $1-5$ tahun & 21 & 36,2 & 18 & 31 \\
\hline & 6-10 tahun & 17 & 29,3 & 24 & 41,4 \\
\hline & $>10$ tahun & 20 & 34,5 & 16 & 27,6 \\
\hline \multirow[t]{3}{*}{ Tingkat Stres Kerja } & Stres Ringan & 1 & 1,7 & 25 & 43,1 \\
\hline & Stres Sedang & 39 & 67,2 & 29 & 50 \\
\hline & Stres Berat & 18 & 31 & 4 & 6,9 \\
\hline
\end{tabular}


Tabel 2 Hubungan Stres Kerja dengan Variabel Bebas

\begin{tabular}{|c|c|c|c|c|c|c|}
\hline \multirow[b]{3}{*}{ Variabel } & & \multicolumn{4}{|c|}{ Stres kerja } & \multirow[b]{3}{*}{ Nilai $p^{*}$} \\
\hline & & \multicolumn{2}{|c|}{ Ringan } & \multicolumn{2}{|c|}{ Sedang Berat } & \\
\hline & & $\mathbf{n}$ & $\%$ & $\mathbf{n}$ & $\%$ & \\
\hline \multirow[t]{2}{*}{ Usia } & 20-40 tahun & 36 & 38,3 & 58 & 61,7 & 0,571 \\
\hline & 41-65 tahun & 7 & 31,8 & 15 & 68,2 & \\
\hline \multirow[t]{2}{*}{ Jenis Kelamin } & Laki-laki & 3 & 20 & 12 & 80 & 0,142 \\
\hline & Perempuan & 40 & 39,6 & 61 & 60,4 & \\
\hline \multirow[t]{2}{*}{ Status Perkawinan } & Belum Menikah & 7 & 30,4 & 16 & 69,6 & 0,462 \\
\hline & Menikah & 36 & 38,7 & 57 & 61,3 & \\
\hline \multirow[t]{2}{*}{ Tempat Kerja } & UGD & 7 & 12,1 & 51 & 87,9 & 0,000 \\
\hline & Rawat Inap & 36 & 62,1 & 22 & 37,9 & \\
\hline \multirow[t]{2}{*}{ Tingkat Pendidikan } & D3 atau D4 & 32 & 34,4 & 61 & 65,6 & 0,233 \\
\hline & S1 & 11 & 47,8 & 12 & 52,2 & \\
\hline \multirow[t]{3}{*}{ Masa Kerja } & 1-5 tahun & 16 & 41 & 23 & 59 & \\
\hline & 6-10 tahun & 18 & 43,9 & 23 & 56,1 & 0,189 \\
\hline & $>10$ tahun & 9 & 25 & 27 & 75 & \\
\hline
\end{tabular}

${ }^{*}$ pearson Chi-Square

Tabel 3 Uji Mann-Whitney perbedaan tingkat stres kerja pada UGD dan rawat inap

\begin{tabular}{llcccc}
\hline & Tempat Kerja & $\mathbf{n}$ & Mann-Whitney U & Z & p Value \\
\hline \multirow{2}{*}{ Tingkat Stres } & UGD & 58 & 841 & $-5,551$ & $0,000^{*}$ \\
& Rawat Inap & 58 & & & \\
& Total & 116 & & & \\
& & & & &
\end{tabular}

${ }^{*} \mathrm{p}<0,05$

Hasil dari korelasi antara stres kerja dengan masa kerja pada Tabel 2 didapatkan nilai p sebesar 0,189, dengan demikian, dapat disimpulkan bahwa masa kerja tidak berhubungan dengan stres kerja.

\section{Uji Mann-Whitney}

Uji ini yaitu Mann-Whitney pada Tabel 3. digunakan untuk melihat apakah terdapat perbedaan tingkat stres (variabel terikat) antara tempat kerja (variabel bebas). Tempat kerja dikategorikan menjadi UGD dan ruangan rawat inap dan tingkat stres dikategorikan menjadi stres sedang berat dan stres ringan.

Berdasarkan uji statistik diperoleh hasil nilai Mann-Whitney $U$ sebesar 841,0 dan nilai p value sebesar 0,000. Sehingga dapat ditentukan $p$ value 0,000 $(\mathrm{p}<0,05)$ atau Ho ditolak. Dengan demikian, maka terdapat perbedaan secara bermakna pada tingkat stres antara perawat yang bertugas di UGD dengan Rawat Inap.

Hasil rerata skor stres pada masing-masing ruang UGD dan ruang rawat inap yaitu 43 pada ruang UGD dan 34 pada ruang rawat inap. Berdasarkan tingkatan stres dari ringan dan sedang berat, pada ruang UGD didapatkan tingkat stres tertinggi yaitu sedang berat sebanyak 51 orang $(87,9 \%)$ sedangkan pada ruang rawat inap didapatkan tingkat stres paling tinggi yaitu stres ringan sebanyak 36 orang $(62,1 \%)$.

\section{PEMBAHASAN}

Pada Tabel 2. Didapatkan hasil usia tidak berhubungan dengan tingkat stres. Pada sebuah penelitian didapatkan hasil yang sama yaitu tidak didapatkan hubungan yang siginfikan antara usia dengan stres kerja. ${ }^{7}$ Sama halnya dengan penelitian di German mengenai hubungan usia dengan stres kerja secara umum tidak didapatkan hubungan yang signifikan antara usia dengan stres kerja. ${ }^{8}$

Hasil uji statistik hubungan antara stres kerja dengan jenis kelamin pada Tabel 2. disimpulkan bahwa Jenis Kelamin tidak berhubungan dengan tingkat stres. Hasil yang sama didapatkan pada penelitian di Amerika dimana tidak ditemukan perbedaan yang signifikan antara laki-laki dan perempuan terhadap stres kerja dan burnout. ${ }^{9}$

Didapatkan juga hasil Status Perkawinan tidak berhubungan dengan tingkat stres pada Tabel 2 . Hasil ini berbeda dengan temuan di India dimana terdapat hubungan antara stres kerja dengan status 
perkawinan wanita yang telah menikah mengalami stres kerja lebih tinggi dibandingkan yang belum menikah. ${ }^{10}$ Hasil yang berbeda ini dikarenakan perbedaan cara pengukuran data serta jumlah sampel yang digunakan.

Berdasarkan Tabel 2. Mengenai hubungan antara stres kerja dengan tempat kerja didapatkan hasil yaitu tempat kerja berhubungan dengan tingkat stres. Dari hasil penelitian yang dilakukan di Manado hal ini dapat terjadi karena lingkungan kerja dapat mempengaruhi kinerja karyawan hasil ini didapatkan dengan nilai $\mathrm{p}=0,009 .{ }^{11}$

Pada Penelitian ini tidak didapatkan hubungan antara tingkat pendidikan dengan stres kerja (Tabel 2). Hasil yang sama juga didapatkan pada penelitian di RSJ Grahasia Yogyakarta yaitu tidak terdapat hubungan antara tingkat pendidikan dengan stres kerja dengan nilai $\mathrm{p}=0,939 .{ }^{12}$

Hasil uji statistik pada Tabel 2. Tidak didapatkan hubungan antara masa kerja dengan stres kerja. Hasil yang berbeda didapatkan dari penelitian yang dilakukan mengenai analisis faktor-faktor yang berhubungan dengan kejadian stres kerja pada karyawan bank didapatkan hasil bahwa masa kerja berhubungan dengan stres kerja dengan nilai $\mathrm{p}=$ $0,015 \cdot{ }^{13}$ Hasil ini berbeda dikarenakan jumlah data subyek serta instrumen yang digunakan berbeda.

Berdasarkan Tabel 3. pada ruang UGD didapatkan tingkat stres tertinggi hal ini dikarenakan pada departemen kegawatdaruratan merupakan suatu lingkungan yang penuh dengan tekanan. Karena pada tempat ini terjadi interaksi dengan anggota tim interdisipliner lainnya serta situasi yang terkait dengan lingkungan gawat darurat seperti trauma, kematian, kesedihan, kegembiraan dan ketidakpastian umum setiap saat. ${ }^{14}$ Tekanan atau stresor yang paling sering diidentifikasi yaitu dari aspek lingkungan kerja, termasuk bagaimana beban kerja, terlalu ramai, kejadian traumatis, shift kerja, konflik antar staf, serta kurangnya kerja tim. ${ }^{15}$

Hasil yang sama didapatkan pada penelitian di Banjarmasin dimana ditemukan perbedaan tingkat stres kerja pada perawat IGD dan rawat inap didapatkan nilai $\mathrm{p}=0,001 .{ }^{16}$ Pada studi yang dilakukan di Rumah Sakit Pancaran Kasih GMIM Manado terdapat perbedaan tingkat stres pada perawat Instalasi Gawat Darurat dengan Ruang Rawat Inap dimana perawat IGD didapatkan menderita stres lebih tinggi daripada perawat Unit Rawat Inap dengan nilai $\mathrm{p}=0,002 \cdot{ }^{17}$

\section{SIMPULAN}

Berdasarkan hasil dan pembahasan dari penelitian "Perbedaan Stres Kerja pada Perawat di Ruang Unit Gawat Darurat dengan Perawat di Ruang Rawat
Inap RS 'S’ di Kota Denpasar Tahun 2017', dapat diambil kesimpulan sebagai berikut. Didapatkan perbedaan yang bermakna pada tingkat stres antara perawat yang bertugas di UGD dengan perawat di ruang rawat inap.

\section{SARAN}

Bagi manajemen Rumah Sakit Sanglah, perlu adanya rotasi atau pertukaran perawat yang telah lama bertugas di Ruang UGD maupun di ruang rawat inap. Bagi perawat di Ruang UGD dan Ruang Rawat Inap pada saat libur sebaiknya perawat benar-benar menggunakan waktunya untuk libur dan beristirahat. Bagi peneliti lain perlu diperhatikan jumlah subyek serta distribusi karakteristik subyek agar data yang didapat bisa mewakili populasi.

\section{DAFTAR PUSTAKA}

1. Widodo. Perbedaan Tingkat Stres Kerja Antara Perawat Kritis dan Perawat Gawat Darurat di RSUD DR. Moewardi Surakarta. Surakarta: Universitas Muhammadiyah Surakarta. Skripsi. 2010.

2. Martina, A. Gambaran Stres Kerja Perawat di Ruang Rawat Inap Rumah Sakit Paru Dr. Moehammad Goenawan Partowidigdo Cisarua Bogor (RSPG). Jakarta: Fakultas Ilmu Keperawatan Universitas Indonesia. Skripsi. 2012.

3. Najimi, A., Goundarzi, A.M., Sharifirad, G. Causes of Job Stress in Nurses: A Cross-Sectional Study. Iranian Journal of Nursing and Midwifery Research. 2012; 17: 301-305.

4. WHO. Stress at The Workplace. Occupational Health Topics. 2007. Tersedia di : http://www.who.int/ occupational_health/topics/stressatwp/en/

5. Sepahvand, E., Mirzaei, M., et al. Evaluation of Occupational Stress and the Effective Factor on it in the Staff of Educational Hospital of Shohada - e - Ashayer of Khoram Abad in 2014. IOSR Journal of Dental and Medical Sciences. 2015. 14(9):80-84.

6. Jusnimar. Gambaran Tingkat Stres Kerja Perawat Intensive Cace Unit (ICU) di Rumah Sakit Kanker Dharmais. Jakarta: Universitas Indonesia. Skripsi. 2012

7. Preston, J., Shipton, H. The Relationship Between Age, Stress and Learning During Organisational Change. Chartered Institute of Personnel and Development Centres Conference, Keele University. 2011.

8. Rauschenbach, C., Krumm, S., Thielgen, M., Hertel, G. Age and Work-related stress: a review and meta-analysis. Journal of Managerial Psychology. 2012. 28 (7/8): 781-804. Tersedia di: http://www.emeraldinsight.com/loi/jmp

9. McCarty, W.P., Zhao, J.S., Garland, B.E. Occupational Stress and Burnout Between Male and Female Police Officer Are There Any Gender Differences?. An International Journal of Police Strategies \& Management. 2007. 30 (4): 672-691. Tersedia di: http://www.emeraldinsight.com/loi/pijpsm

10. Parveen, Nagina. Investigating Occupational Stress Among Married and Unmarried Working Woman In Hyderabad City. Bahria Journal of Professional Psychology. 2009. 5: 21-37.

11. Potu, Aurelia. Kepemimpinan, Motivasi, dan Lingkungan Kerja Pengaruhnya Terhadap Kinerja Karyawan pada Kanwil Ditjen Kekayaan Negara Suluttenggo dan Maluku Utara di Manado. Jurnal EMBA. 2013. 1 (4): 1208-1218.

12. Aiska, S. Analisi Faktor-Faktor yang Berpengaruh pada Tingkat Stres Kerja Perawat di Rumah Sakit Jiwa Grhasia Yogyakarta. Yogyakarta: Universitas Muhammadiyah Yogyakarta. Skripsi. 2014. 
13. Fitri, Azizah Musliha. Analisis Faktor-Faktor Yang Berhubungan Dengan Kejadian Stres Kerja Pada Karyawan Bank (Studi Pada Karyawan Bank BMT). Semarang : Jurnal Kesehatan Masyarakat UNDIP. 2013. 2(1).

14. Heglund, S.D. Stressor Experienced By Emergency Department Registered Nurses At The Bedside : A Phenomenological Study. College of Nursing at the University of Central Florida Orlando, Florida. 2012.

15. Healy, S., Tyrrell, M. Stress in Emergency Departments : Experiences of Nurse and Doctors. Emergency Nurse. 2011. 19 (4):31-37.

16. Rosadi, D., Rahman, F., Yulia, V., Rahman, M.A., et al. Perbedaan Tingkat Stres Kerja pada Perawat Instalasi Gawat Darurat (IGD) dan Unit Rawat Inap di RSUD DR. H. Moch. Ansari Saleh Banjarmasin. Fakultas Ilmu Kesehatan Universitas Pekalongan. 2015.
17. Mulyadi, L.K. Perbedaan Tingkat Stres Kerja Perawat Instalasi Gawat Darurat dan Unit Rawat Inap di Rumah Sakit Pancaran Kasih GMIM Manado. eJournal Keperawatan Universitas Sam Ratulangi. 2015. 3(1).

18. Prasanty, D, Husada, M.S, Effendy, E, SImbolon, M.J. Work-related psychological distress and social dysfunction in Nurses at Haji Hospital Medan-Indonesia. Bali Med J. 2018. 7(2):279-284.

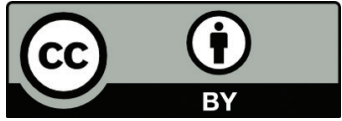

This work is licensed under a Creative Commons Attribution 